\title{
Diet and trophic structure of the fish assemblage in the mid-course of the Teles Pires River, Tapajós River basin, Brazil
}

\author{
Eurizângela P. Dary ${ }^{1}$, Efrem Ferreira ${ }^{2}$, Jansen Zuanon² and Cristhiana P. Röpke ${ }^{1,3}$
}

This study was carried out in a section of the middle course of the Teles Pires River, a clear water river that drains ancient and highly eroded geological formations, and where five hydropower plants are planned or in construction. In this study we tested the hypothesis that local fish fauna is mainly sustained by autochthonous food resources, with modest changes in the trophic structure of fish assemblages along the hydrometric cycle. Sampling was performed every three months between July 2008 and May 2009 at seven sites distributed along a 50-km section of the river. Piscivores was the most representative group in terms of biomass, abundance and species richness, followed by herbivores, insectivores and omnivores. The trophic structure did not change significantly during the hydrometric cycle, only omnivores showed significant temporal variation in abundance. The main food resources consumed by the ichthyofauna were of autochthonous origin, mainly immature aquatic insects and fish. Eight of 34 species showed temporal variations of the food resources consumed. Our results corroborate the hypothesis that the fish fauna of large, clear water rivers can be sustained by autochthonous resources. This contributes to understanding some determinants of fish production in large Neotropical rivers.

Keywords: Amazon, Environmental impact, Food resources, Temporal dynamics, Trophic ecology.

Este estudo foi desenvolvido em um trecho do curso médio do rio Teles Pires, um rio de águas claras que drena regiões de terreno geologicamente antigos, e onde cinco usinas hidrelétricas estão previstas ou em construção. Dado a transparência da água e as características do terreno nos hipotetizamos que a fauna de peixes local é principalmente sustentada por recurso autóctone e com alterações pouco significativas na estrutura trófica ao longo de um ciclo hidrométrico. As amostragens foram realizadas trimestralmente entre julho/2008 e maio/2009 em sete pontos dispostos ao longo de um trecho de cerca de $50 \mathrm{~km}$ do rio. Piscívoros foram os mais representativos em biomassa, número de exemplares e riqueza de espécies, seguidos pelos herbívoros, insetívoros e onívoros. Não houve mudança significativa na estrutura trófica da assembleia ao longo do ciclo hidrométrico, apenas onívoros apresentaram significativa variação temporal na abundância. Os principais recursos alimentares utilizados pela ictiofauna foram de origem autóctone, sobretudo insetos imaturos e peixes. Oito de 34 espécies apresentaram variação temporal na dieta. Os resultados corroboram a hipótese de que grandes rios de água clara podem ser sustentados majoritariamente por recursos autóctone. Desta forma, este estudo contribui para a compreensão de alguns fatores determinantes da produção secundária em grandes rios Neotropicais.

Palavras-chave: Amazônia, Dinâmica temporal, Ecologia trófica, Impacto ambiental, Recurso alimentar.

\section{Introduction}

Given the importance of estimating and predicting fish biomass, fishery sustainability, and understanding fish diversity, larger rivers are often the focus of trophic ecology studies. Due to the usual high biomass and diversity of fishes, large rivers in the Neotropical region provide a good opportunity to understand processes related to secondary production (Roach, 2013; Humphries et al., 2014). Many conceptual models such as the River Continuum Concept (Vannote et al., 1980), the Flood Pulse Concept (Junk et al., 1989), and the Riverine Productivity Model (Thorp, Delong, 2002), were developed to explain variations in primary and secondary production over space and time. Empirical studies have supported contrasting hypotheses to explain the most important factors influencing the sources of basal production that support secondary production, including: hydrologic regime, turbidity, concentrations of dissolved organic matter, lateral connectivity between the river channel and floodplain, and amount of floodplain vegetation (see Roach, 2013 and Humphries et al., 2014 for a review).

\footnotetext{
${ }^{1}$ Programa de Pós-Graduação em Biologia de Água Doce e Pesca Interior, Instituto Nacional de Pesquisas da Amazônia-INPA, Av. André Araújo, 2036, Petrópolis, 69067-375, Manaus, AM, Brazil. (EPD) euridary@gmail.com (corresponding author), (CPR) krikaropke@gmail.com ${ }^{2}$ Coordenação de Biodiversidade-COBIO, Instituto Nacional de Pesquisas da Amazônia-INPA, Av. André Araújo, 2036, Petrópolis, 69067-375, Manaus, AM, Brasil. (EF) efrem@inpa.gov.br, (JZ) zuanon@inpa.gov.br

${ }^{3}$ Faculdade de Ciências Agrárias, Universidade Federal do Amazonas, 69077-000 Manaus, AM, Brazil.
} 
Hydrologic and geomorphologic characteristics influence river turbidity and can act as key features to predict basal sources of primary production that sustain the trophic structure of aquatic assemblages (Roach, 2013; Humphries et al., 2014). After an extensive compilation of studies, Roach (2013) pointed out to a relatively major importance of autochthonous food resources in clear water watersheds, while allochthonous resources seem to be more important under increased turbidity/low transparency river systems (e.g. muddy and black waters). However, seasonality can regulate the relative importance of autochtonous and allochthonous resources when determining changes in turbidity (Roach, 2013). Low turbidity throughout the hydrometric cycle is a remarkable characteristic of clear water rivers draining the Brazilian and Guiana Shields in the Neotropical region. Few studies in these rivers have focused on the origin of resources sustaining fish fauna while also considering the seasonal variation. For instance, ZuluagaGómez et al. (2016), using stable isotopes and suggest that clear water rivers are mainly sustained by autochthones sources; but the effect of seasonality was not considered in the study.

Seasonal changes in the relative importance of trophic resources are highlighted in the Flood Pulse Concept (Junk et al., 1989), and studies conducted in aquatic environments of lowland river-floodplain systems have been the major source of empirical evidences that support this theoretical concept (e.g. Goulding et al., 1988; Claro-Junior et al., 2004; Mérona, Rankin-de-Mérona, 2004; Röpke et al., 2014). These studies have shown remarkable seasonal dynamics in the trophic structure and food resources consumption by fish that are related to changes in food resources available when riparian forest is flooded (Goulding, 1980; Goulding et al., 1988; Goulding et al., 2003; Correa, Winemiller, 2014). However, most such studies were focused on lowland rivers, so that the importance of seasonality in shaping food resources consumed by fish of highland rivers are still scarce (Flausino-Junior et al., 2016).

Most trophic studies in highland clear water basins such as Trombetas and Mucajaí rivers were focused on fish assemblage' trophic structure and have indicated the presence of high biomasses of piscivorous and herbivorous fishes (Ferreira et al., 1988; Ferreira, 1993). On the other hand, studies in lowland river-floodplain systems have evidenced a greater biomass of detritivorous and omnivorous or invertivorous fishes (e.g. Araújo-Lima et al., 1995; Pouilly et al., 2004; Mérona, Rankin-de-Mérona, 2004). A higher occurrence of specialized feeding strategies is reported for fish assemblage in clear water highland rivers than in turbid floodplain rivers (e.g. Zuanon, 1999; Flausino-Junior et al., 2016; Zuluaga-Gómez et al., 2016). However, in both highland and floodplain rivers, fishes utilize a wide diversity of food items (Goulding et al., 1988; Zuanon Ferreira, 2008; Flausino-Junior et al., 2016).

Ecological characteristics of Neotropical clear water watersheds in highlands with rapids and waterfalls, have been poorly studied (Bohlke et al., 1978; Goulding et al., 2003; Torrente-Vilara et al., 2011), but these environments are highly praised for the construction of hydroelectric power plants. With the growing interest in installing new hydroelectric plants in these environments, studies on this type of environment is enforced by Brazilian law, but most of the information generated concerning the ichthyofauna is of limited access, and mostly restricted to unpublished technical reports (Zuanon, 1999).

The Teles Pires River basin is located within a priority area for natural resource conservation (Ayres et al., 2005; Silva et al., 2005) but has nonetheless long been subjected to anthropogenic impacts, especially those related to deforestation and gold-mining (Akagi et al., 1994; Malm et al., 1995; Bidone et al., 1997; Hacon et al., 1997; Fearnside, 2001; Goulding et al., 2003). This basin has also attracted the interest of the energy sector in Brazil due to its geomorphological characteristics that are considered favorable to the construction of hydroelectric dams (RadamBrasil, 1980; Souza, 2008). Five hydroelectric plants were planned for construction in the basin (EPE, 2009), and since 2011, four plants (UHE São Manoel, UHE Teles Pires, UHE Colíder and UHE Sinop) have obtained official permission for installation, which are now in different phases of construction (PAC, 2016).

Here we bring data based on fish surveys along a 50 $\mathrm{km}$ section of the middle portion of the Teles Pires River, which corresponds to the area to be impacted by the São Manoel Hydroelectric Power Plant. We conducted a broad stomach contents analysis of the local fish fauna aiming at: i) characterizing the trophic structure of the local fish assemblage and verifying its possible temporal variation in relation to the different phases of the hydrometric cycle; ii) evaluate the importance of autochthonous and allochthonous food items on the diet of the fish assemblage and along the hydrometric cycle; and, iii) to verifying if the most common and most abundant species that shift the items consumed among hydrometric periods. Considering the narrow range of floodplain forest present in the mid portion of the Teles Pires River and the high water transparency, we hypothesize that the local fish fauna is mainly sustained by autochthonous food sources, with modest changes in the trophic structure of fish assemblages along the hydrometric cycle.

\section{Material and Methods}

Study area. The Teles Pires River is located in the Southern Amazon basin (Fig. 1A) and drains the Central Brazilian Shield (Sioli, 1984). Originating in the municipality of Paranatinga, in Mato Grosso State, the river flows to the north through the Planalto dos Parecis until meeting the Juruena River and forming the Tapajós River. Along its course of approximately $1,400 \mathrm{~km}$, the Teles Pires River terrain has several variations in altitude, which create many rapids and waterfalls. The regional climate is tropical with high rainfall during the austral summer (mean annual precipitation 
$>2,750 \mathrm{~mm}$ ). The vegetation reflects a transition from Amazon Forest to central-western Neotropical Savannah, with predominance of contacts between ombrophilous forests/savannah and savannah/seasonal forests (sensu RadamBrasil, 1980; SEPLAN, 2008).

The Teles Pires River has many distinct environmental characteristics in common with other rivers that drain from Central Brazil and Guiana shields (i.e. Xingu and Trombetas rivers). It's clear and nutrient-poor waters, drain ancient and highly eroded geological formations, resulting in low aquatic primary production compared to rivers flowing from the Andes (Goulding et al., 2003). In the Teles Pires River there are many waterfalls and rapids and the main channel has high banks with relatively small floodplains (Sioli, 1984, Goulding et al., 2003). As most large rivers in tropical region, the Teles Pires River encompasses an annual variation of the water level of approximately six meters primarily driven by regional rainfall (Sioli, 1984; Goulding et al., 2003).
The study area was a $50-\mathrm{km}$ section of the mid-course of the Teles Pires River, from immediately downstream of the Sete Quedas waterfall to the mouth of the São Benedito River (Fig. 1B). The channel is circa 420 meter wide with numerous rocky islands colonized by small- to mediumsized plants and shrubs and several large rapids, where aquatic rheofilous Podostemacean plants grows. The largest and most turbulent rapids in this section are Cachorro and Macacos rapids, with about $22 \mathrm{~km}$ of linear distance from each other. The altitudinal gradient results in expressive geomorphologic changes, creating spatial heterogeneity over the $50 \mathrm{~km}$ of the study area: the river section between the Sete Quedas and Macacos rapids (L6) has a channel ranging from 250 to 560 meter wide with high banks, numerous smaller rapids, and some areas with slow current; the most downstream section (L7) has a wider channel with 700 meter wide in average, slower current, and lower banks. Over the studied $50-\mathrm{km}$ river stretch the riparian vegetation was abundant and well preserved on the river bank.

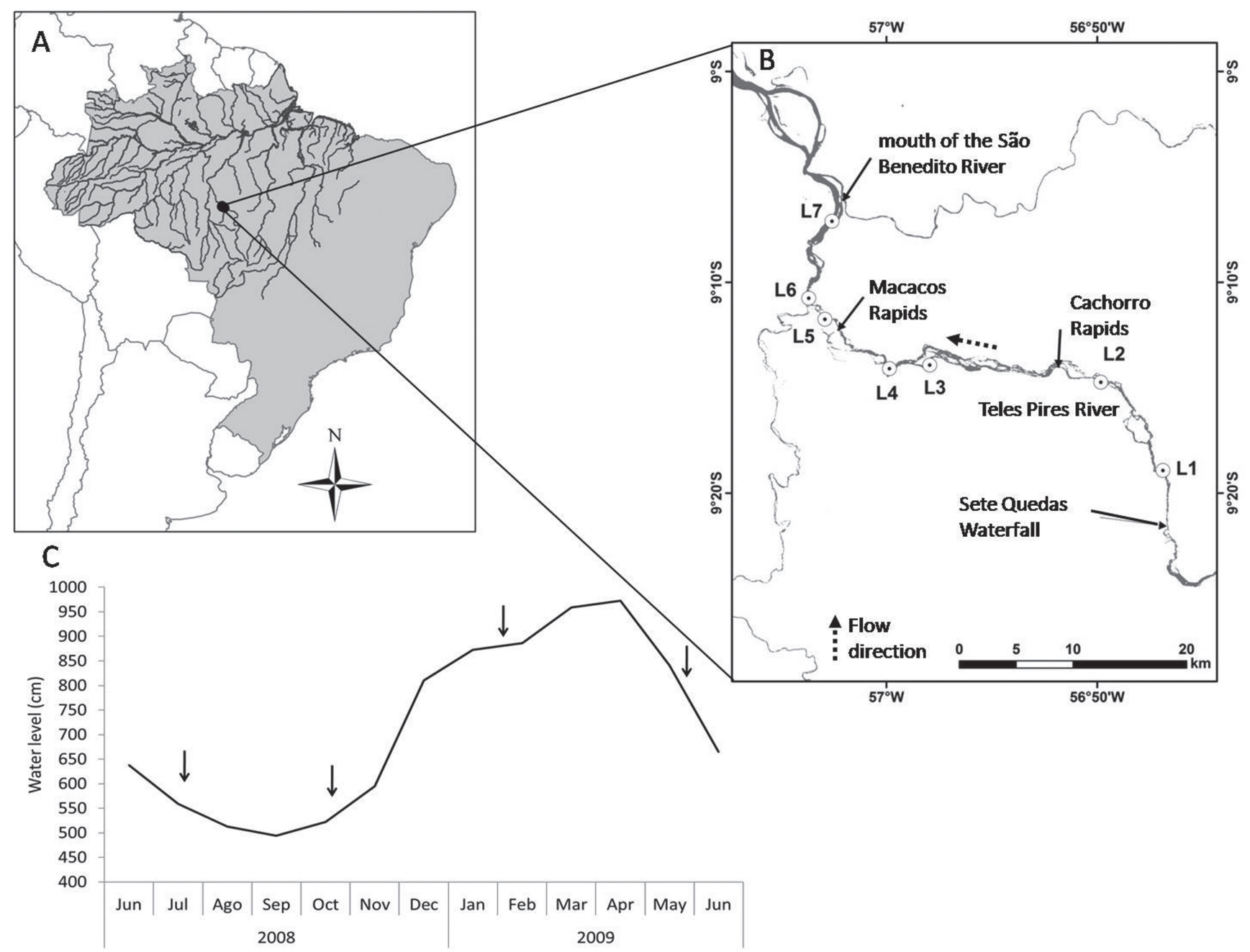

Fig. 1. A: Map of the portion of the Amazon River basin in Brazil (South America), with a detail of the Teles Pires River. B: Study area on the Teles Pires River, indicating (by arrows) the sampling sites and seven sampling points (L1-L7). C: Water level of the Teles Pires River during the study period; the arrows indicate fish sampling events. River level data provided by Agência Nacional de Águas (ANA). 


\section{Fish sampling}

Fish samplings were conducted every three months from July/2008 to May/2009, which included the main phases of the annual hydrological cycle: dry, rising, flood, and receding (Fig. 1C). Seven sampling points were established based on the position of the planned São Manoel dam in the Macacos rapids and of its projected impact area (Fig. 1B). Four sampling points were located upstream from the Macacos rapids (L1 - L4) and three downstream of it (L5 - L7). Each locality was sampled using a set of 10 gillnets (mesh size $24-120 \mathrm{~mm}$ between opposing knots) resulting in a total coverage of $247 \mathrm{~m}^{2}$. The nets remained deployed for 24 consecutive hours and were checked in the early morning (6 a.m.), at midday, and at the end of the day (6 p.m.). The gillnets where not checked at night because of the risks of navigating in the rapids. All specimens that were not dead when removed from the nets were euthanized on ice.

The collected fish were identified, weighted (in grams), and measured (standard length, in $\mathrm{cm}$ ). The digestive tract of the specimens was removed, labeled for identification, and stored individually in plastic bags containing $10 \%$ formalin solution and subsequently conserved in $70 \%$ ethanol. Voucher specimens of most fish species were preserved and deposited at INPA's Fish Collection (INPA-ICT) (http:// portalcolecoesdb.inpa.gov.br/ictiologia/).

Analyses of diets, trophic classifications and origin of food resources. The food items consumed were identified to the most precise taxonomic level possible and the evaluation of its importance was based on the combined information of frequency of occurrence (FO) (cf. Hyslop, 1980) and relative volume (RV) (Soares, 1979). The volume of each food type was visually estimated as a percentage of the total content (Goulding et al., 1988), and those values subsequently multiplied by the degree of repletion of the stomachs (GR), using the interval of fullness proposed by Goulding et al. (1988), as 10, 25, 50, 75 and $100 \%$. The results of FO were associated to RV in the Alimentary Importance Index (IAi), modified from Kawakami, Vazzoler (1980). IAi values were calculated for each species based on the pooled data from the complete hydrometric cycle and for the seven sampling points; calculations were made for each hydrometric period separately only for species collected in at least three periods.

Slightly more than $70 \%$ of the collected species ( 66 species and 859 specimens) had their stomach contents analyzed. Of the 66 species collected, 34 had a minimum of four specimens with stomach contents over the hydrometric cycle and their trophic classification was based exclusively on observations made during the present study. Trophic classifications for the other species with $\mathrm{N}<4$ stomach contents were determined using information from specialized literature available at species level (or, when unavailable, at genus level). The trophic category classification of each species was determined based on the predominant food types ingested or by pooling of similar food items in its $\operatorname{diet}(\mathrm{IAi} \geq 50 \%)$.

\section{Statistical analysis}

Trophic structure of the ichthyofauna was evaluated based on data of species richness, biomass (total weight), and numerical abundance per trophic category. These parameters were estimated based on CPUE values (Catch per Unit Effort), measured in relation to the standardized collection effort used at each sampling event (number of species, numerical abundance or total weight of the fish $/ 247 \mathrm{~m}^{2}$ of net collection area/24 hours of sampling). Possible seasonal variation in the trophic structure of the ichthyofauna was tested comparing values of biomass, numerical abundance and richness ( $\log _{10}+1$ transformed to reach normality) among periods of the hydrometric cycle, using Analysis of Variance (ANOVAs) with a Tukey's post-hoc test (Zar, 1999).

To determine the origin (aquatic or terrestrial) of the principal food resources used by each trophic group, and to check for temporal variations in its consumption by the whole fish fauna, we assumed that the fish were efficient samplers of the food resources available in their environment (Sale, 1974; Winemiller, Pianka, 1990; Wootton, 1990; Winemiller, KelsoWinemiller, 1996; Gaspar da Luz et al., 2001). The origin of the food items consumed was then classified as: autochthonous resources when originating from the aquatic environment, including immature forms of insects, zooplankton, benthic invertebrates, algae, aquatic macrophytes, and fish; or allochthonous resources when originating from terrestrial environment such as fruits, seeds, and immature and adult forms of terrestrial insects; and undetermined origin when it was not possible to determine if the item was from aquatic or terrestrial environment, such as small insect fragments and detritus. IAi values were assigned to the food resources according to their origin (autochthonous or allochthonous), for each sampling point and hydrometric period, and its relative importance compared using paired Student's $t$ test (p-value $<0.05$ ) (Zar, 1999), considering only items of known origin.

The identification of possible ontogenetic variation in source use was done by comparing the IAi values of the different food items for each species in different size classes. The size classes were determined according to Sturges' rule (Sturges, 1926, Pires et al., 2016).

Possible seasonal variation in resource utilization for those species that occurred in at least three periods and with $\mathrm{N} \geq 4$ was done by comparing the IAi values of the different food items in the diet of each species for each period. All statistical analyses were performed using Statistica 10.0 software.

\section{Results}

Trophic classification, assemblage structure and origin of food resources. A total of 1,385 specimens belonging to 90 species were captured. Most of the samples were composed by small to medium-sized fishes (maximum standard length up to $30 \mathrm{~cm}$ ); however, Hydrolycus armatus (Jardine, 1841), Boulengerella cuvieri (Spix \& Agassiz, 1829), and Electrophorus electricus (Linnaeus, 1766), attained 
more than $70 \mathrm{~cm}$ (Appendix S1 - Available only as online supplementary file accessed with the online version of the article at http://www.scielo.br/ni). Based on diet information (Tab. 1), the fish species were classified into seven trophic categories: carnivores, species that consumed fish and aquatic and/or terrestrial invertebrates without predominance of any item; detritivores, species that consumed mainly particulate organic material in different stages of decomposition together with mineral particles; herbivores, represented by species that consumed terrestrial and/or aquatic vascular plant material, and/or algae; insectivores, species that predominantly consumed aquatic insects and secondarily by species that consumed mainly terrestrial insects; invertivores, the ones which consumed insects as well as other invertebrates with no predominance ( $\mathrm{IAi} \geq 50 \%$ ) of one type; omnivores, consumed items of both vegetal and animal origins in similar proportion; piscivores, which ingested whole fish or pieces of muscle or fins and scales. See Appendix (S1 - Available only as online supplementary file accessed with the online version of the article at http://www.scielo.br/ni) for further details about stomach contents.

Piscivores was the most representative trophic category in terms of biomass, numerical abundance, and species richness (Fig. 2). Two species in this trophic category, B. cuvieri and $H$. armatus (predators of small characids) were responsible for approximately $35 \%$ of the total fish biomass captured although they contributed less than $10 \%$ of the total numerical abundance. The lepidoghagous Roeboides aff. descalvadensis was the most abundant species in the catches, representing slightly more than $5 \%$ of the total fish abundance and 33\% of the piscivores abundance (Tab. 1). Herbivores, insectivores, and omnivores were the second most representative groups in terms of biomass, numerical abundance, and species richness respectively (Fig. 2). Among the herbivores, Myloplus torquatus (Kner, 1858) stood out, as it was responsible for approximately $15 \%$ of the total biomass and $8 \%$ of the total abundance (considering all species collected), as well as $45 \%$ of the biomass of herbivores. Insectivores represented $18 \%$ of the total numerical abundance, with Ageneiosus apiaka Ribeiro, Rapp Py-Daniel \& Walsh, 2017 (12\% of the total; $40 \%$ of this group) and Bryconops alburnoides Kner, 1858 ( $9 \%$ of the total; $28 \%$ of this group) being the most abundant species in this category. Among the omnivores, Pterodoras granulosus (Valenciennes, 1821) (72.12), Leporinus friderici (Bloch, 1794) (12.06\%), Leporinus affinis Günther, 1864 (3.36\%), Hemiodus aff. semitaeniatus Kner, 1858 (2.84\%), Sartor cf. tucuruiense Santos \& Jégu, 1987 (2.51\%), Leporinus cylindriformis Borodin, 1929 (2.45\%), and Hemiodus immaculatus Kner, 1858 (1.46\%) were the most representative in biomass, in terms of abundance the most representative species were Hemiodus aff. semitaeniatus (24.24\%) and Moenkhausia megalops (Eigenmann, 1907) (15.15\%).

Regarding the origin of the resources consumed by each trophic group, allochthonous items were the most important only for herbivores (IAi pooled allochthonous items: 74.44; see Tab. 1 for further details). For all other trophic groups, autochthonous items were predominant in the diet (omnivores: IAi pooled autochthonous items 61.35; detritivores: pooled $\mathrm{IA} i=64.82$; insectivores: pooled $\mathrm{IA} i=$ 75.74; invertivores: pooled $\mathrm{IAi}=76.43$; piscivores pooled $\mathrm{IAi}=99.46$ (Tab. 1 for further details).

Seasonality of the assemblage trophic structure, origin of resources and species' diets. Seasonal differences in the trophic structure of the assemblage were only significant for numerical abundance of omnivores $(\mathrm{F}=3.523, \mathrm{p}=$ $0.030, n=28$ ), with lower abundance during the flood period compared to the rising (Tukey $\mathrm{p}=0.020$ ) (Fig. 2). For all other trophic groups (as well for the biomass and richness of omnivores) there were no differences among periods (see Appendix S2 - Available only as online supplementary file accessed with the online version of the article at http://www. scielo.br/ni for complete ANOVA results).

Along the hydrometric cycle, with exception of the rising period, there was a predominance of consumption of autochthonous resources $[\mathrm{t}=-3.979, \mathrm{p}<0.001, \mathrm{n}=28$; $\mathrm{t}$ tests for each period: dry $(\mathrm{t}=-2.966, \mathrm{p}=0.025, \mathrm{n}=7)$, rising $(\mathrm{t}=-0.230$, $\mathrm{p}=0.990, \mathrm{n}=7)$, flooding $(\mathrm{t}=-2.530, \mathrm{p}=0.044, \mathrm{n}=7)$, and receding $(\mathrm{t}=-3.907, \mathrm{p}=0.007, \mathrm{n}=7)]$. Among autochthonous food resources, aquatic insects (predominantly immatures larva and nymphs - of Ephemeroptera) and fish (represented especially by scales) were the most important items in fish diets (Tab. 1 and Appendix S3 - Available only as online supplementary file accessed with the online version of the article at http://www.scielo.br/ni).

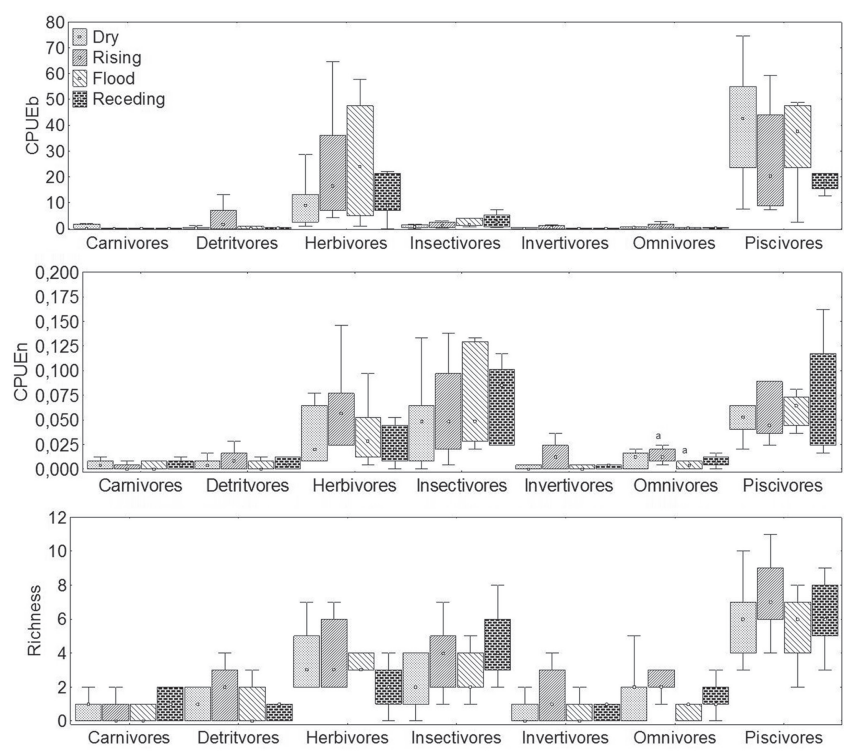

Fig. 2. Representation of the trophic categories on fish assemblage structure in the mid-course of the Teles Pires River in terms of biomass (CPUEb), numerical abundance (CPUEn), and species richness by hydrometric periods (dry, rising, flood and receding) estimated by Capture per Unit Effort $\left(247 \mathrm{~m}^{2} / 24 \mathrm{hs}\right)$. Letter "a" identify averages that differed significantly between periods according to Tukey's Test. 

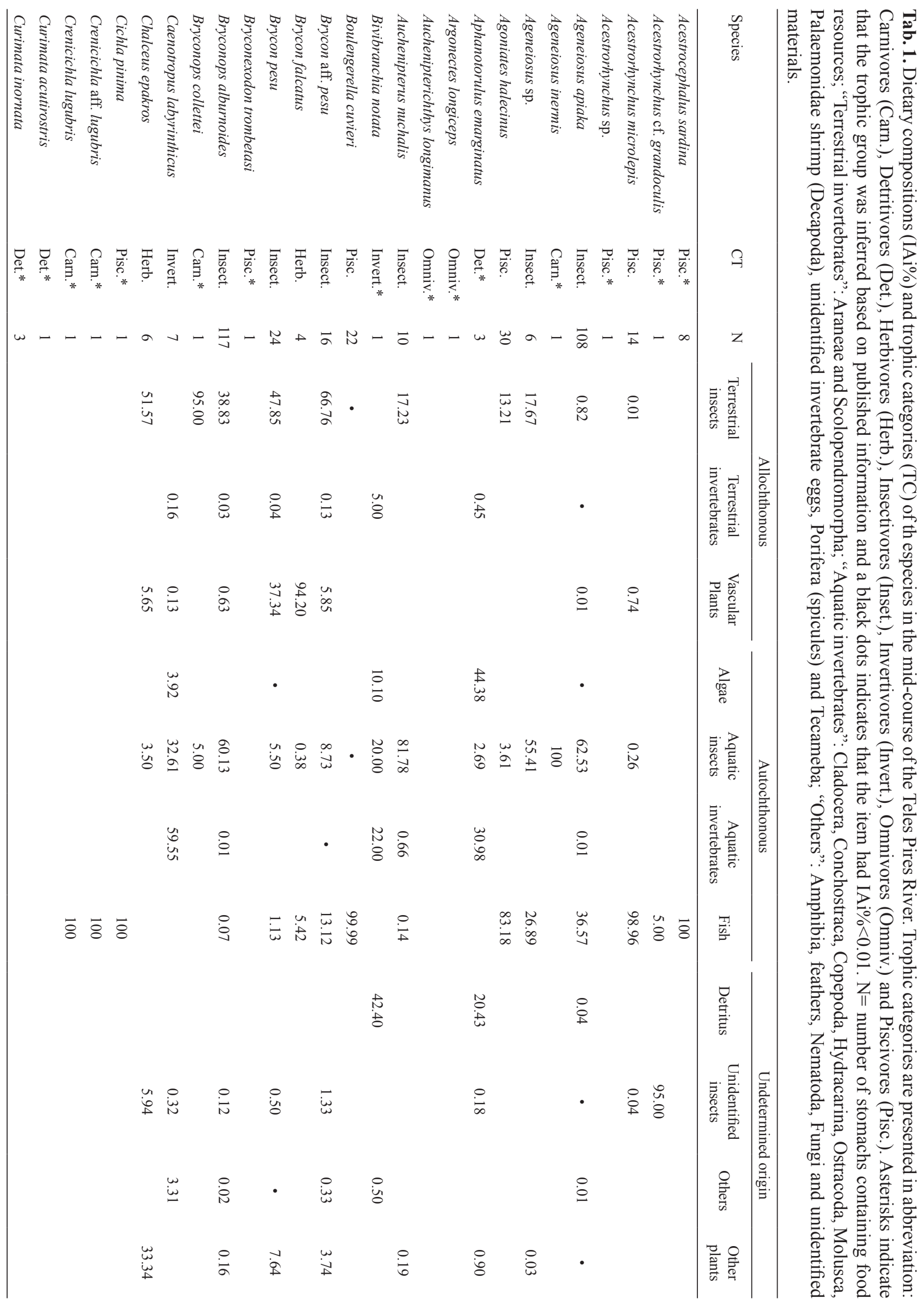


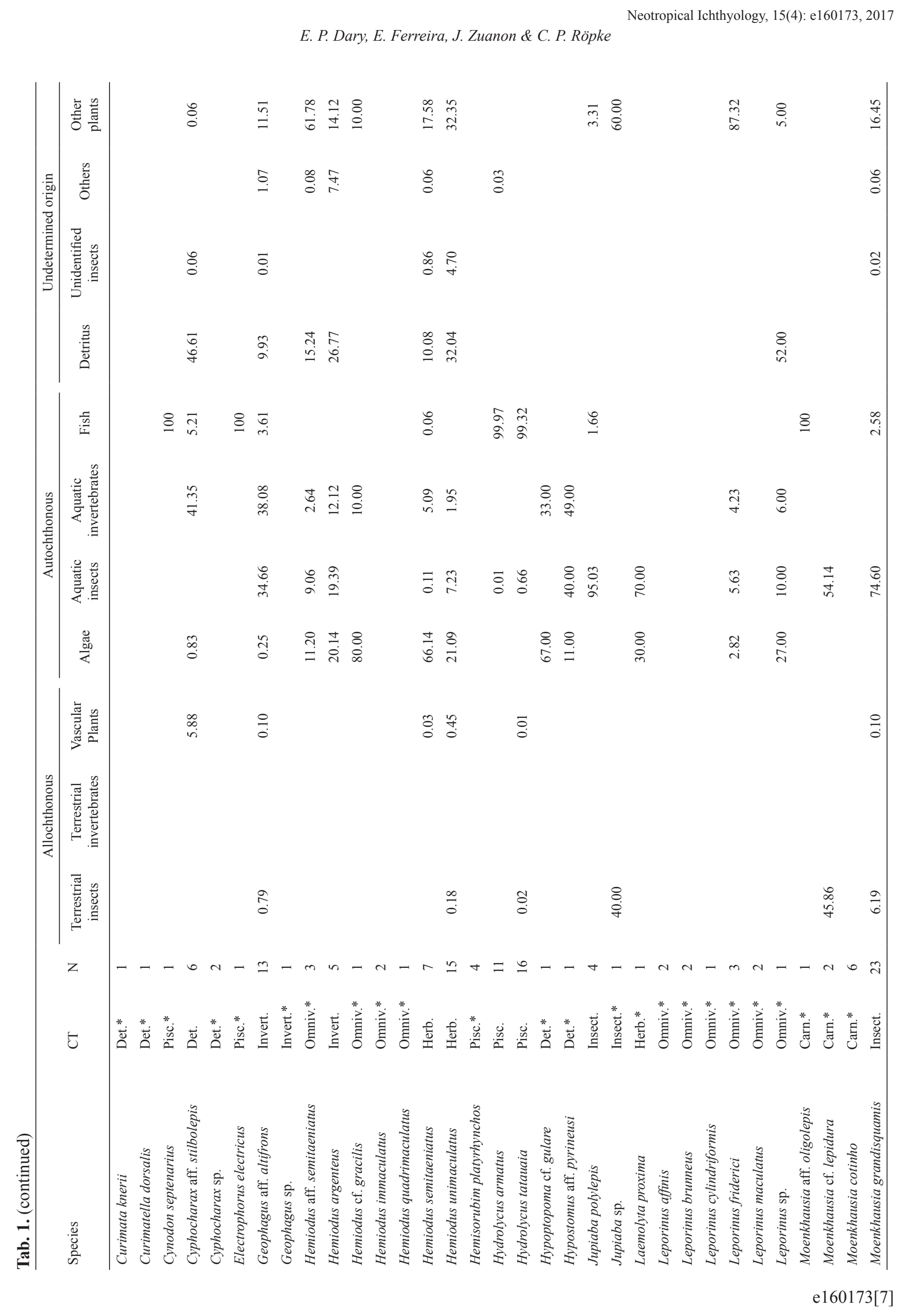




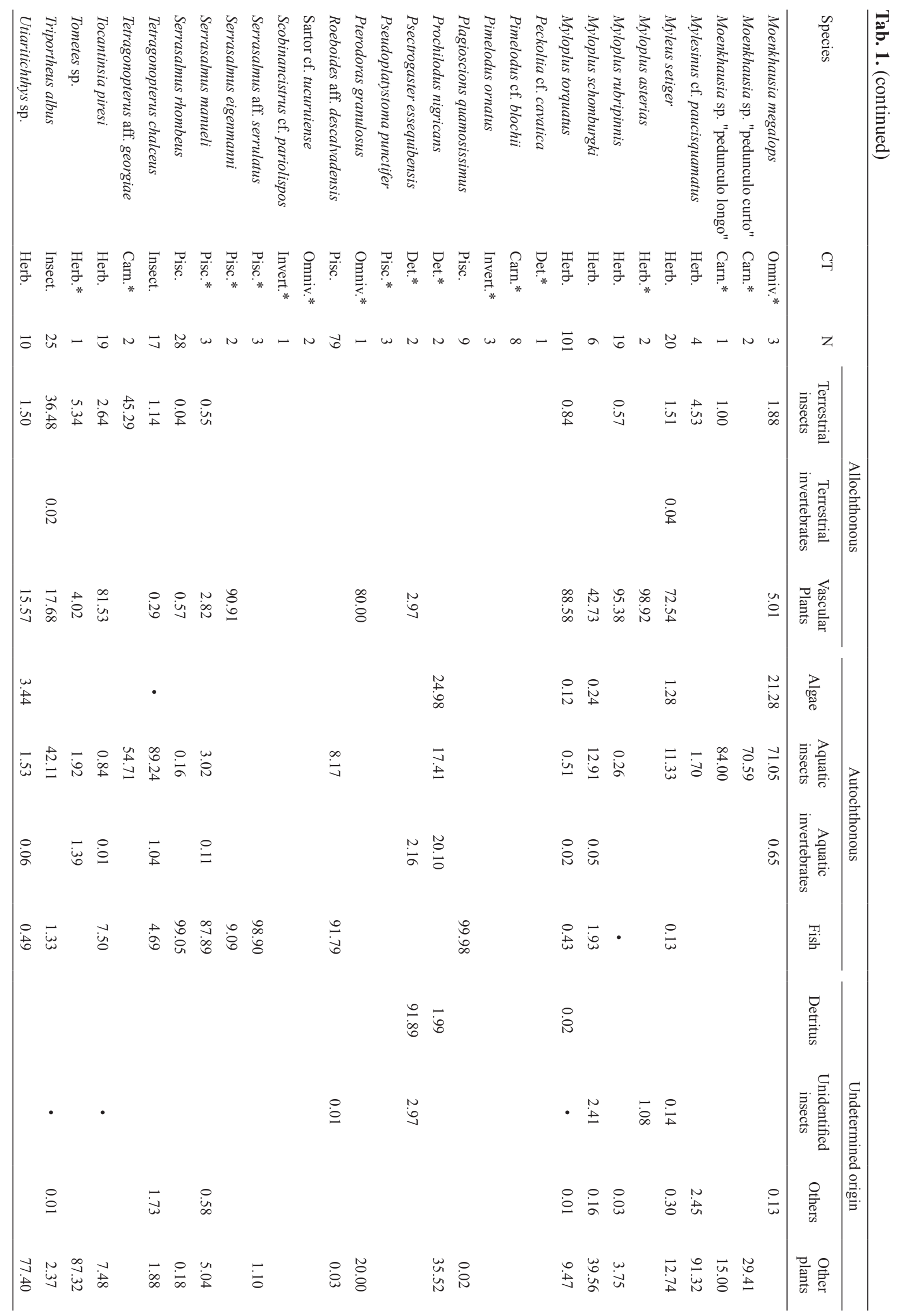


Ontogenetic variations in species' diets were not observed (Appendix S4 - Available only as online supplementary file accessed with the online version of the article at http://www. scielo.br/ni), however, eight species that were captured in at least three of the four hydrometric periods demonstrated temporal variation in the food resources consumed (Fig. 3 and Appendix S5 - Available only as online supplementary file accessed with the online version of the article at http://www. scielo.br/ni). Ageneiosus apiaka predominantly consumed aquatic insects during the dry (Ephemeroptera 73.36, Odonata 6.72, Trichoptera 5.68), flood (Ephemeroptera 90.07) and receding periods (Ephemeroptera 60.65, Diptera 4.00), and fish (scales 66.29, Characidae 9.05) during rising waters. Agoniates halecinus Müller \& Troschel, 1845 predominantly consumed terrestrial insects (Isoptera 71.42) during rising, and fish in the flood and receding periods (Characidae 84.63, fish fragments 2.10, and Characidae 93.10; scales 2.07, respectively). Brycon aff. pesu Müller \& Troschel, 1845 consumed terrestrial insects (Hymenoptera 53.19, Diptera 7.45), and fish (fish fragments 17.73) in the rising period and receding period (Hymenoptera 49.79, Coleoptera 8.53) when it also fed on fish (Characidae 14.21), however during the flood it fed mainly on vascular plants (seeds 40.69 , Flowers 11.19). Brycon pesu predominantly consumed vascular plants (leaves 33.10, flowers 28.49, roots/stems 4.19; seeds 68.84, fruits 6.31, flowers 3.69; Unidentified plants 34.61) and terrestrial insects (Unidentified terrestrial insects 26.82, Coleoptera 3.49, Hymenoptera 3.07; Hymenoptera 11.81, Orthoptera 2.72; Hymenoptera 26.21) during dry, flood and receding periods, respectively, although in the rising periods it fed mainly on terrestrial insects (Coleoptera 72.78, Hymenoptera 2.14). Bryconops alburnoides predominantly consumed aquatic insects (Ephemeroptera 83.24, Unidentified aquatic insects 3.89) in the dry, and terrestrial insects (Hymenoptera 59.82, Coleoptera 11.52, Unidentified terrestrial insects 3.53 ) during the rising period, but consumed similar proportions of aquatic and terrestrial insects in the flood and receding periods, with an increase in the volume of plant items (Unidentified plants 9.74) all along flood. Hemiodus unimaculatus (Bloch, 1794) changed feeding on plants (Unidentified plants 47.31) to detritus (51.72) and unidentified plants (32.14) from dry season to rising, respectively, and algae (34.70) during receding. Moenkhausia grandisquamis (Müller \& Troschel, 1845) predominantly consumed aquatic insects (rising: Coleoptera 29.70, Unidentified aquatic insects 28.84; flood: Ephemeroptera 61.36; receding: Ephemeroptera 81.50) during all three periods in which it was collected, but the secondary resources changed from fish (Characidae 18.56) to plants (Unidentified plants 27.19) and terrestrial insects (Hymenoptera 9.76), and to plants (Unidentified plants 11.72 ) in rising, flood and receding periods respectively. Roeboides aff. descalvadensis predominantly consumed fish scales during the dry (96.86), and receding (99.71) periods, which had reduced importance in the diet in the rising period, while aquatic insects increased (scales 65.80, Diptera 32.90).
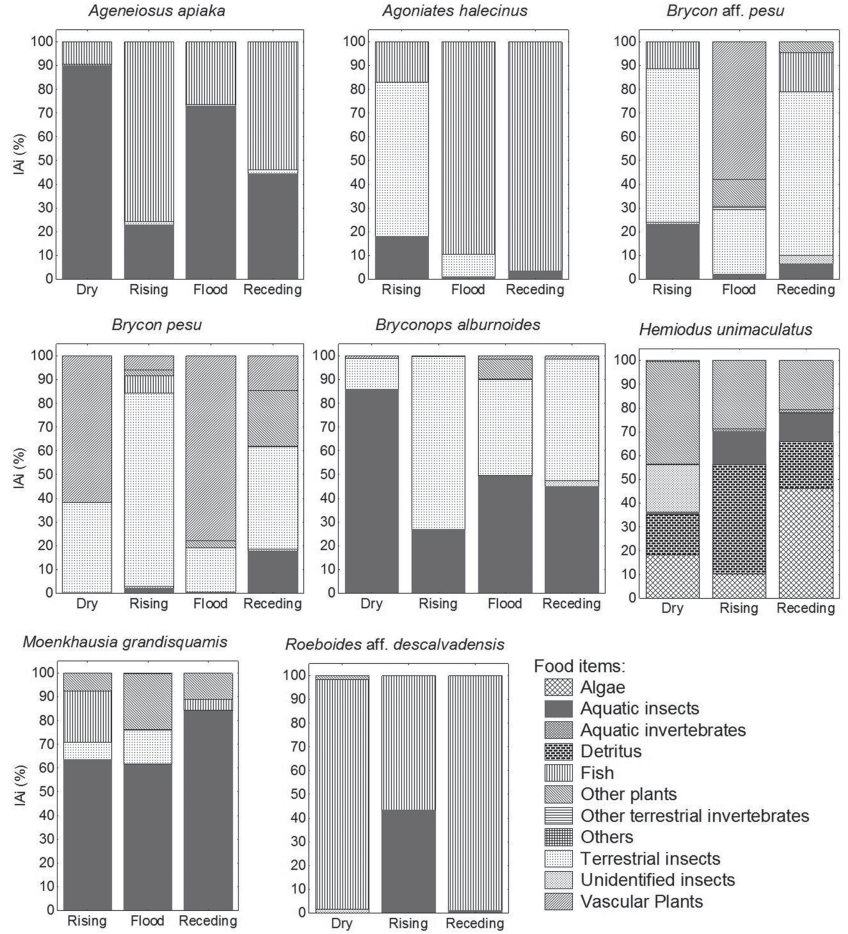

Fig. 3. Diet composition of the most representative species during the different hydrometric periods in the mid-course of the Teles Pires River.

\section{Discussion}

The trophic structure of the fish assemblage at the midcourse of the Teles Pires River was mostly stable during the entire hydrometric cycle, an interesting result considering that piscivores were the trophic group with the greatest richness, abundance, and biomass. Major representability of this trophic group in fish assemblages were also reported by Ferreira et al. (1988), Ferreira (1993), and Zuanon (1999) for the Mucajaí, Trombetas, and Xingu respectively, rivers that also drain from the Guiana and Brazilian Shields and have geomorphologies similar to the Teles Pires River. Similar to found in Teles Pires River, herbivorous (including algivorous) and insectivorous fishes also made a large part of the biomass and abundance in those clearwater rivers (Ferreira et al., 1988; Ferreira, 1993; Zuanon, 1999). This indicates that shield clear-water rivers with relatively lower primary productivity (when compared to Amazonian white waters; see Melack, Forsberg, 2001) can nevertheless sustain high biomasses, possibly due to a fast assimilation of the local productivity into fish biomass.

The relative minor importance of detritivores in our samples suggests that the biomass of piscivores may be sustained mostly by omnivorous, insectivorous, and herbivorous prey fishes. This result contrasts with findings for other rivers in the Amazon (Bayley, 1973, Angelini et al., 2006) and Orinoco (Winemiller, Jepsen, 1998) basins, where detritivores were the most important group sustaining the piscivores. Omnivores, insectivores, and herbivores 
did not vary on biomass and abundance over the year in the Teles Pires River. Only the abundance of omnivores was reduced during the flood when compared to the rising period, which may have resulted from the dispersion of these fishes to marginal areas or longitudinally in the river channel. A possible explanation for the stability is abundance and biomass of these trophic categories would be that many species within these categories are relatively small in size (insectivores: 40-216 mm SL- standard length; omnivores: 53-275 mm, Appendix S1 - Available only as online supplementary file accessed with the online version of the article at http://www.scielo.br/ni), and have shorter life cycles, which would allow rapid population growth and sizes, which may sustain high abundance and diversity of predatory fishes (Winemiller, 2005). On the other hand, most species of herbivores are large-sized, suggesting that they are not easily preyed, at least by the piscivores recorded in our study (e.g. Acestrorhynchus spp., Agoniates halecinus, Boulengella cuvieri, Cichla pinima, Cynodon septeniarus, Hydrolycus spp.). Observational and experimental studies have found that a stable prey biomass does not depend only on basal resources (Borer et al., 2006) but also that the diversity of predators and preys enhance production and stability of prey biomass (Fox, 2004). In fact, herbivores, insectivores and omnivores were the most diverse groups in the study area.

Previous studies in clear water rivers such as Mucajaí, Trombetas, Xingu, and Aripuanã, all of which having limnological characteristics similar to the Teles Pires River, found that food resources consumed by fishes were predominantly of autochthonous origin (Ferreira et al., 1988; Ferreira, 1993; Zuanon, 1999; Flausino-Junior et al., 2016; Zuluaga-Gómez et al., 2016). The present study has shown that the fish assemblage exploit a wide variety of food resources, including algae, terrestrial plant material, terrestrial invertebrates, and detritus. Herbivores was the only category to consume mainly allochthonous items, which was represented by plant parts from the riparian forest, like flowers, fruits and seeds, which were consumed along the year by large-sized fishes such as Brycon spp., Mylopus spp. and Metynnis spp. This strong interaction between these herbivorous fishes and riparian forest is well known in floodplain rivers in the Amazon basin (e.g. Goulding, 1980; Goulding et al., 1988; Ferreira (1993), Mérona, Rankin-deMérona, 2004; Correa, Winemiller, 2014).

The River Continuum Concept of Vannote et al. (1980) posits that the relative importance of allochthonous resources in relation to autochthonous resources gradually decreases from the headwaters to the mouths of large rivers as they widen and deepen. Differently, the Flood Pulse Concept postulated by Junk et al. (1989), as well as other observational studies (Goulding et al., 1988; Roach, 2013) suggest that the seasonal flood pulses result in strong variation in the relative importance of allochthonous and autochthonous food items as a consequence of changes in environmental conditions (e.g. water column transparency and photosynthesis). Another important point of this concept is that primary production is mainly originated at the floodplain vegetation and not at the main river channel. An important role of local channel primary production in supporting the aquatic fauna was proposed by the Riverine Productivity concept proposed by Thorp, Delong (1994; 2002). According to this concept, algae are generally more nutritious and labile than material from terrestrial plants, and an algae pathway may support a significant secondary production of biomass (Thorp, Delong, 1994, 2002). A recent study of fish trophic ecology using stable isotopes in the Xingu River found that small benthic algae was the most important source sustaining fish biomass (ZuluagaGómez et al., 2016), supporting the Riverine Productive Model. The predominance of autochthonous resources in fish diets throughout the seasonal hydrometric cycle of the Teles Pires River, as well as the very narrow floodplain apparently increases the importance of local productivity thus lending support to the Riverine Productive Model However, independent lines of evidence such as from stable isotopes analyzes.

An explanation for the comparatively higher importance of autochthonous energy sources to the fish fauna of the mid portion of the Teles Pires River would be that in the intermediate courses of rivers (the region studied here), a combination of factors such as the greater incidence and penetrance of light due to the clear water characteristics, and the availability of various types of habitats and substrates would favor the establishment of large and diverse aquatic invertebrates populations that could be consumed by fish throughout the entire hydrometric cycle (Vannote et al., 1980; Lowe-McConnell, 1999; Zuanon, Ferreira, 2008). The rocky substrate predominant in the study area not only allows the establishment of Podostemaceae plants but also permits a dense cover of periphytic algae on the structure provided by these macrophytes. This rich habitat is colonized by a wide diversity of aquatic invertebrates that constitute the base of a complex food chain capable of sustaining a wide diversity of fish species in environments with rapids and waterfalls (Zuanon, 1999; Zuanon, Ferreira, 2008; Flausino-Junior et al., 2016).

The species which have shown dietary seasonal changes were in general small- to medium- sized omnivores or invertivores. The exceptions to others trophic categories were Roeboides aff. descalvadensis, Ageneiosus apiaka, Agoniates halecinus, and Hemiodus unimaculatus. Roeboides aff. descalvadensis is a scale eater that shifted the diet to include insects as the predominant item in diet during the rising season. Ageneiosus apiaka feeds mostly on insects, but shifted the diet to include fish as the predominant item during the rising season. Agoniates halecinus consumed fish during most seasons, but shifted to terrestrial insects during the rising season. Finally, $H$. unimaculatus changed the diet to include algae instead of the typical consumption of detritus. All the observed changes in diet were not related to ontogenetic shifts (Appendix S4 - Available only as online 
supplementary file accessed with the online version of the article at http://www.scielo.br/ni). Most of the observed changes in the diet of the assemblage were observed in the rising period, which may be related to a higher diversity of food items due to the increased availability of habitats following the inundation of the river margins. The changes observed in the diet of Roeboides aff. descalvadensis (which is a specialized scale-eater) probably indicates the ability of this species to utilize other food items whose availability is increased seasonally. Generalist and opportunistic feeding strategies have been recorded in different environments in Neotropical river basins, especially those subjected to strong temporal changes in environmental conditions that modify habitat quality and food supply (e.g. Ferreira, 1993; Mérona, Rankin-de-Mérona, 2004; Pouilly et al., 2004; Ximenes et al., 2011; Correa, Winemiller, 2014; Röpke et al., 2014). Species able to change the diet according to the seasonal availability of food may become predomina in the aquatic environment ollowing river impoundment by dam construction, as food availability will be severely modified to a new (and nearly permanent) environmental condition.

Previous studies had shown a high diversity of food types and feeding strategies by the fish fauna in rivers with rapids and waterfalls (Zuanon, 1999; Zuanon, Ferreira, 2008; Flausino-Junior et al., 2016), with several species showing trophic specialists. However, except piscivores, no evident trophic specializations were identified by the fish fauna of the studied reach of Teles Pires River. One possible explanation could be that the Teles Pires River is subjected to a much larger variability in food resources among seasons, as compared to Xingu and Aripuanã rivers, for instance, impair colonization or evolution development of local feeding specializations. On the other hand, this apparent lack of specialization may be an artifact, since the same food resources can be exploited by means of different feeding tactics, at different microhabitats and time schedules, which could only be checked by through direct naturalistic observations (e.g. Zuanon, 1999; Flausino-Junior et al., 2016).

It is evident that the ongoing construction of hydroelectric power plants along the Teles Pires River will result in numerous environmental alterations, including modifications of the local hydrological dynamics and the overall structure and availability of aquatic habitats. After the formation of a reservoir, the structure of the fish assemblages become dramatically altered, with many species being locally extirpated and others greatly increasing in abundance. We also anticipate that shore regions will become especially important for providing structural complexity and to maintain the remaining part of the original fish diversity. Rocky areas of the rapids harbor a very rich biological assemblages but will become flooded by the reservoir and unavailable as foraging sites for the fish fauna (Zuanon, 1999; Agostinho et al., 2007; Agostinho et al., 2009).

The loss of riparian vegetation and the rapid habitats, combined with the expected changes in hydrometric regime will likely change the food web dynamics. Among the possible changes in trophic structure of the assemblage, it could be expected a reduction of the abundance and biomass of herbivores and insectivores as suggested by their its dependency on riparian food resources, which will possibly e effect on the biomass of piscivorous fishes. These changes can also result in loss of stability of the trophic structure due to the increased abundance fluctuation of the trophic groups, especially during the earlier phases of the reservoir development. The results of the present study should help in quantifying the impacts of the dam construction on the trophic structure of the fish assemblage, by providing a baseline for future comparative studies in the Teles Pires River basin.

Our study indicates that the trophic structure of the fish assemblage of Teles Pires River has a low seasonal variability with a predominance of piscivores and herbivores in terms of biomass and species richness, and of insectivores in terms of abundance. The most common occurring species were able to switch some of its main food resources among hydrometric periods, suggesting that resource availability change temporally but without a significant effect on the abundance of trophic groups. The local fish fauna is sustained mainly by autochthones resources, which is similar to the observed for other clear water rivers draining from ancient regions, such as Guiana and Brazilian shields in South America (Zuluaga-Gómez et al., 2016) and may suggest a pattern for such large rivers. However, evidences from stable isotopes studies should be used to test this hypothesis. In fact, The results presented here corroborate the hypothesis that autochthonous sources are more important than allochthonous in clear water environments that lack large floodplains (Roach, 2013), contributing to increasing our understanding on secondary production of freshwater tropical rivers.

\section{Acknowledgments}

This work was supported by the Brazilian National Council for Scientific and Technological Development $(\mathrm{CNPq})$ that provided a study grant to EPD, CPR and a productivity grant to JZ (process 313183/2014-7); CPR receives a fellowship from CAPES (PNPD); CONCREMAT provided funding for collecting trips and support for field activities. We are grateful to Tiago Pires and Akemi Shibuya for their comments about the text and language review and the anonymous reviewers for their valuable comments.

\section{References}

Agostinho AA, Gomes LC, Pelicice FM. Ecologia e manejo de recursos pesqueiros em reservatórios do Brasil. Maringá: EDUEM; 2007.

Agostinho CS, Pelicice FM, Marques EE, organizers. Reservatório de Peixe Angical: bases ecológicas para o manejo da ictiofauna. São Carlos: Rima; 2009. 
Akagi H, Yoshihide K, Branches F, Malm O, Harada M, Pfeiffer WC, Kato H. Methylmercury Pollution in Tapajós River Basin, Amazon. Environmental Sciences. 1994; 3:25-32.

Angelini R, Fabrè NN, Silva Júnior UL. Trophic analysis and fishing simulation of the biggest Amazonian catfish. Afr J Agric Res. 2006; 1(5):151-58.

Araújo-Lima CARM, Agostinho AA, Fabrè NN. Trophic aspects of fish communities in Brazilian rivers and reservoirs. In: Tundisi JB, Bicudo CEM, Matsumura-Tundisi T, editors. Limnology in Brazil. São Paulo: ABC/SBL; 1995. p.105-136.

Ayres JM, Fonseca GAB, Rylands AB, Queiroz HL, Pinto LP, Masterson D, Cavalcanti RB. Os Corredores Ecológicos das Florestas Tropicais do Brasil. Belém: Sociedade Civil Mamirauá - SCM; 2005.

Bayley PB. Studies on the migratory characin, Prochilodus platensis Holmberg 1889 (Pisces, Characoidei) in the Rio Pilcomayo, South America. J Fish Biol. 1973; 5(1):25-40.

Bidone ED, Castilho ZC, Cid de Souza TM, Lacerda LD. Fish contamination and human exposure to mercury in the Tapajós river basin, Pará State, Amazon, Brazil: A screening approach. Bull Environ Contam Toxicol. 1997; 59(2):194-201.

Böhlke JE, Weitzman SH, Menezes NA. Estado atual da sistemática dos peixes de água doce da América do Sul. Acta Amazon. 1978; 8(4):657-77.

Borer ET, Halpern BS, Seabloom EW. Asymmetry in community regulation: effects of predators and productivity. Ecology. 2006; 87(11):2813-20.

Claro-Junior L, Ferreira E, Zuanon J, Araujo-Lima C. O efeito da floresta alagada na alimentação de três espécies de peixes onívoros em lagos de várzea da Amazônia central, Brasil. Acta Amazon. 2004; 34(1):133-37.

Correa SB, Winemiller KO. Niche partitioning among frugivorous fishes in response to fluctuating resources in the Amazonian floodplain forest. Ecology. 2014; 95(1):210-24.

Empresa de Pesquisa Energética (EPE). Avaliação Ambiental Integrada da Bacia Hidrográfica do Rio Teles Pires. 2009. Available from: http://www.aneel.gov.br/aplicacoes/ noticias_area/dsp_detalheNoticia.cfm?idNoticia $=2683 \& \mathrm{i}$ dAreaNoticia $=414 \mathrm{http}: / /$ ww.epe.gov.br/MeioAmbiente/ Documents/AAI\%20Teles\%20Pires/AAI\%20Teles\%20 Pires\%20-\%20AAD\%20e\%20conflitos\%20-\%20Sum.\%20 Executivo.pdf. (Date of Access-November 25, 2015).

Fearnside PM. Soybean cultivation as a threat to the environment in Brazil. Environmental Conservation. 2001; 28(1):23-38.

Ferreira EJG. Composição, distribuição e aspectos ecológicos da Ictiofauna de um trecho do rio Trombetas, na área de influência da futura UHE Cachoeira Porteira, estado do Pará, Brasil. Acta Amazon. 1993; 23(Suppl.):1-89.

Ferreira EJG, Santos GM, Jégu M. Aspectos ecológicos da ictiofauna do rio Mucajaí, na área da ilha do Paredão, Roraima, Brasil. Amazoniana, 1988; 10(3):339-52.

Flausino-Junior N, Machado FA, Zuanon JS, Ferreira EJ. The fish fauna of sessile hydrophytes stands (Mourera spp.: Podostemaceae) in the Dardanelos Waterffalls, Rio Aripuanã, Brazil. Aqua, International Journal of Icthyology, 2016; 22(3):133-44.
Fox JW. Modelling the joint effects of predator and prey diversity on total prey biomass. J Anim Ecol. 2004; 73(1):88-96.

Gaspar da Luz KD, Abujanra F, Agostinho AA, Gomes LC. Caracterização trófica da ictiofauna de três lagoas da planície aluvial do alto rio Paraná, Brasil. Acta Sci Biol Sci. 2001; 23(2):401-07.

Goulding M. The Fishes and the forest: exploration in Amazonian natural history. Los Angeles: University of California Press; 1980.

Goulding M, Carvalho ML, Ferreira EG. Rio Negro, rich life in poor water: Amazonian diversity and ecology as seen throught fish communities. The Netherlands: SPB Academic Publishing; 1988.

Goulding M, Barthem R, Ferreira EJG. The Smithsonian Atlas of the Amazon. Washington: Smithsonian Books; 2003.

Hacon S, Rochedo ERR, Campos RRR, Lacerda LD. Mercury exposure through fish consumption in the urban area of Alta Floresta in the Amazon basin. J Geochem Explor. 1997; 58(2-3):209-16.

Humphries P, Keckeis H, Finlayson B. The River Wave Concept: Integrating River Ecosystem Models. BioScience. 2014; 64(10):870-82.

Hyslop EJ. Stomach contents analysis- a review of methods and their application. J Fish Biol. 1980; 17(4):411-29.

Junk WJ, Bayley PB, Sparks RE. The flood pulse concept in riverfloodplain systems. In: Dodge DP, editor. Proceedings of the International Large River Symposium. Can Spec Publ Fish Aquat Sci: Canadian Government Publishing Centre/Canada Communication Group; 1989; 110-27.

Kawakami E, Vazzoler G. Método gráfico e estimativa de índice alimentar aplicado no estudo de alimentação de peixes. Bol Inst Oceanogr. 1980; 29(2):205-07.

Lowe-McConnell RH. Estudos ecológicos de comunidades de peixes tropicais. São Paulo: Edusp; 1999.

Malm O, Branches FJP, Akagi H, Castro MB, Pfeiffer WC, Harada M, Bastos WR, Kato H. Mercury and methyl mercury in fish and human hair from the Tapajós river basin, Brazil.Sci Total Environ. 1995; 175(2):141-50.

Melack JM, Forsberg BR. Biogeochemistry of Amazon floodplain lakes and associated wetlands. In: McClain ME, Victoria RL, Richey JE, editors. Biogeochemistry of the Amazon Basin. Oxford: Oxford University; 2001; p.210-260.

Mérona B, Rankin-de-Mérona J. Food resource partitioning in a fish community of the central Amazon floodplain. Neotrop Ichthyol. 2004; 2(2):75-84.

Programa de Aceleração do Crescimento (PAC). Available from: http://www.pac.gov.br/infraestrutura-energetica/geracaode-energia-eletrica. (Date of Access - December 15, 2016).

Pires THS, Farago TB, Campos DF, Cardoso GM, Zuanon J. Traits of a lineage with extraordinary geographical range: ecology, behavior and life-history of the sailfin tetra Crenuchus spilurus. Environ Biol Fishes. 2016; 99(12):925-37.

Pouilly M, Yunoki T, Rosales C, Torres L. Trophic structure of fish assemblages from Mamoré River floodplain lakes (Bolivia). Ecol Freshw Fish. 2004; 13(4):245-57. 
RadamBrasil. Folha SC. 21 Juruena: geologia, geomorfologia, pedologia, vegetação, uso potencial da terra / Projeto RadamBrasil. Volume 20. Rio de Janeiro, Departamento Nacional de Produção Mineral; 1980.

Roach KA. Environmental factors affecting incorporation of terrestrial material into large river food webs.Freshw Sci. 2013; 32(1):283-98.

Röpke CP, Ferreira E, Zuanon J. Seasonal changes in the use of feeding resources by fish in stands of aquatic macrophytes in an Amazonian floodplain, Brazil. Envion Biol Fishes, 2014; 97(4):401-14.

Sale PF. Overlap in resource use and interspecific competition. Oecologia, 1974; 17(3):245-56.

SEPLAN - Secretaria de Estado de Planejamento e Coordenação Geral. Available from: www.seplan.mt.gov.br. (Date of Access - July 31, 2008).

Silva JMC, Fonseca GBA, Cavalcanti RB. O corredor dos ecótonos Sul-Amazônicos. In: Ayres JM, Fonseca GAB, Rylands AB, Queiroz HL, Pinto LP, Masterson D, Cavacanti RB, editors. Corredores Ecológicos das Florestas Tropicais do Brasil. Belém: Sociedade Civil Mamirauá - SCM; 2005. p.254-256.

Sioli H. The Amazon and its main influents: hydrography, morphology of the river courses, and river types. In: Sioli H, editor. The Amazon: Limnology and landscape ecology of a mighty tropical river and its basin. Dordrecht: Dr. W. Junk Publishers; 1984. p.127-165.

Soares MGM. Aspectos ecológicos (alimentação e reprodução) dos peixes do igarapé do Porto, Aripuanã, MT. Acta Amazon. 1979; 9(2):325-52.

Sousa RR. Análise preliminar da preferência das chuvas na Amazônia Mato-Grossense no período de 2004 a 2007 (janeiro, fevereiro e março). Rev Geogr Acadêmica. 2008; 2(1):56-72.

Sturges HA. The choice of a class interval. J Am Stat Assoc. 1926; 21(153):65-66.

Thorp JH, Delong MD. The Riverine Productivity Model: An Heuristic View of Carbon Sources and Organic Processing in Large River Ecosystems. Oikos. 1994; 70(2):305-08.

Thorp JH, Delong MD. Dominance of autochthonous autotrophic carbon in food webs of heterotrophic rivers. Oikos. 2002; 96(3):543-50.
Torrente-Vilara G, Zuanon J, Leprieur F, Oberdorff T, Tedesco PA. Effects of natural rapids and waterfalls on fish assemblage structure in the Madeira River (Amazon Basin). Ecol Freshw Fish. 2011; 20(4):588-97.

Vannote RL, Minshall GW, Cummins KW, Sedell JR, Cushing CE. The River Continuum Concept. Can J Fish Aquat Sci. 1980; 37(1):130-37.

Winemiller KO. Life history strategies, population regulation, and implications for fisheries management. Can J Fish Aquat Sci. 2005; 62:872-85.

Winemiller KO, Pianka ER. Organization in natural assemblages of desert lizards and tropical fishes. Ecol Monogr. 1990; 60(1):27-55.

Winemiller KO, Kelso-Winemiller LC. Comparative ecology of catfishes of the Upper Zambezi River floodplain. J Fish Biol. 1996; 49(6):1043-61.

Winemiller KO, Jepsen DB. Effects of seasonality and fish movement on tropical river food webs. J Fish Biol. 1998; 53 (Suppl. A):267-96.

Wootton RJ. Ecology of teleost fishes. London: Chapman \& Hall, 1990.

Ximenes LQL, Mateus LAF, Penha JMF. Temporal and Spatial variation in composition of feeding guilds of the fish fauna of oxbow lakes of the Cuiabá River, Northern Pantanal. Biota Neotropica. 2011; 11(1):205-16.

Zar JH. Biostatistical Analysis. New Jersey: Prentice Hall; 1999.

Zuanon JA, Ferreira E. Feeding Ecology of Fishes in the Brazilian Amazon - A naturalistic approach. In: Cyrino JEP, Bureau DP, Kapoor BG, editors. Feeding and digestive functions of fishes. Enfield: Science Publishers; 2008. p.1-34.

Zuanon JAS. História natural da ictiofauna de corredeiras do rio Xingu, na região de Altamira, Pará. [PhD Thesis] Campinas, SP: Universidade Estadual de Campinas; 1999.

Zuluaga-Gómez MA, Fitzgerald DB, Giarrizzo T, Winemiller KO. Morphologic and trophic diversity of fish assemblages in rapids of the Xingu River, a major Amazon tributary and region of endemism. Environ Biol Fishes. 2016; 99(8-9):647-58.

Submitted April 06, 2016 Accepted September 26, 2017 by Rosemara Fugi 
